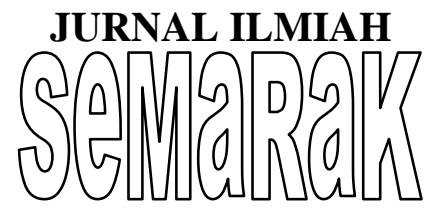

P-ISSN 2615-6849

Jurnal Semarak,Vol. 1,No.1,Februari 2018 , Hal (13-30)

@Prodi Manajemen Fakultas Ekonomi Universitas Pamulang

\title{
ANALISIS KEPUASAN ANGGOTA TERHADAP PELAYANAN KOPEGTEL RAJAWALI DI PT.TELKOM JAKARTA SELATAN
}

\author{
SENEN \\ Dosen Fakultas Ekonomi Universitas Pamulang \\ Email: abdisantosasenen@gmail.com
}

\begin{abstract}
ABSTRAK
KOPEGTEL Rajawali kegiatan usahanya, sebagai perusahaan yang bergerak dalam bidang penjual lasa dan barang sangat mendambakan adanya loyalitas dari anggota/pelanggan. Pelanggan/anggota yang puas akan menjadi repeat-custumer yang senantiasa melakukan pembelian ulang atas barang dan jasa yang ditawarkan oleh KOPEGTEL Rajawali.. Saat ini pesaing sangat ketat diantara perusahaan yang sejenis sehingga mau tidak mau KOPEGTEL rajawali harus mempertahankan pelanggan/anggota yang sudah ada. Melalui penelitian ini penulis ingin mengetahui bagaimana pelaksanaan pelayanan KOPEGTEL Rajawali, serta sejauh mana kepuasan anggota terhadap pelayanan kopegtel rajawali. Penelitian dilakukan terhadap100 responden yang seluruhnya adalah anggota pengguna jasa KOPEGTEL Rajawali. Metode yang digunakan adalah metode penelitian bersifat diskriptif, yaitu metode yang meneliti suatu obyek sehingga hasil penafsiran dan pembahasan akan disampaikan sesuai dengan hasil penelitian yang faktual dan akurat. Berdasarkan hasil penelitian dapat disimpulkan bahwa pelayanan KOPEGTEL Rajawali memuaskan anggota dengan tingkat kepuasan sebesar $75,31 \%$. Hasil penelitian ini dapat digunakan manajemen KOPEGTEL Rajawali sebagai bahan acuan untuk menentukan kebijakan lebih lanjut.
\end{abstract}

Kata Kunci: koperasi, kepuasan anggota, pelayanan.

\section{ABSTRACT}

KOPEGTEL its business activities, the Eagle as a company engaged in the field of the seller and the goods very lasa yearn the existence of loyalty from members/customers. Customers/members are satisfied will be repeat-custumer constantly re-purchase of goods and services offered by the KOPEGTEL an eagle. The current very tight competition among companies of its kind so inevitably KOPEGTEL Eagle should retain customers/existing members. Through these studies the authors wanted to know how the implementation of service KOPEGTEL an eagle, as well as the extent to which the member satisfaction against kopegtel an eagle. Research conducted terhadap100 respondents who are all members of the service users KOPEGTEL an eagle. Based on the results of the study it can be concluded that the Ministry of the KOPEGTEL an Eagle member with satisfactory levels of satisfaction of $75.31 \%$. The results of this research can be used as an ingredient of Eagle KOPEGTEL management reference to determine further policy.

Keywords: cooperatives, member satisfaction, service. 


\section{PENDAHUluAN}

\section{A. Latar Belakang}

Proses pembangunan yang dijalankan selama ini di Indonesia, menjadikan sektor ekonomi sebagai salah satu sektor yang diprioritaskan, namun pada pencapaiannya tentu saja dihadapkan pada tantangan dan permasalahan yang kini semakin berat. Dalam menghadapi tantangan dan permasalahan yang ada pada era globalisasi saat ini hendaknya tetap dapat melihat dan memanfaatkan peluang dalam perkembangan, baik ditingkat nasional, regional maupun global untuk memacu pertumbuhan ekonomi nasional.

Peran koperasi sangat penting dan strategis bagi pererkonomian nasional dalam menghadapi persaingan era pasar global saat ini, dan era ini merupakan peluang baru untuk dapat mengembangkan pembangunan dan mencapai masyarakat adil dan makmur. Koperasi merupakan badan usaha yang mempunyai landasan konstitusional yang sekaligus sebagai gerakan ekonomi rakyat dengan kualitas dan kemandiriannya merupakan soko guru perekonomian nasional, sehingga diharapkan melalui koperasi pembangunan nasional dan kesejahteraan rakyat dapat ditingkatkan.

Dengan kondisi koperasi di Indonesia saat ini, masyarakat punya kepentingan untuk menyelamatkan dan mengembangkan koperasi di era perdagangan bebas yang akan datang, selain itu pemerintah juga mempunyai kewajiban untuk mengembangkan dan memberikan arahan demi terwujudnya iklim usaha yang sehat demi pembangunan dunia usaha khususnya bagi koperasi maupun bentuk - bentuk usaha lainnya, dengan melalui penciptaan kerangka kebijakan dan peraturan yang mendukung terciptanya iklim usaha yang sehat. Selain itu pembangunan koperasi harus diarahkan, agar koperasi tumbuh menjadi sebuah lembaga usaha yang kuat sekaligus sebagai wadah untuk pembinaan kemampuan ekonomi rakyat, serta mempunyai kegiatan usaha yang didasarkan atas kepentingan para anggota sehingga koperasi dapat memenuhi kebutuhan para anggotanya sekaligus dapat memenuhi kebutuhan masyarakat di lingkungan koperasi.

Koperasi rajawali merupakan lembaga ekonomi yang mengelola unit usaha simpan pinjam dan unit usaha toko. Unit toko adalah salah satu kegiatan koperasi rajawali yang menyediakan berbagai kebutuhan barang - barang konsumsi untuk memenuhi kebutuhan dan keinginan anggota. Suatu kenyataan yang dihadapi oleh unit toko koperasi rajawali adalah adanya anggota yang merasa kurang mendapat layanan yang memuaskan. Pada dasarnya anggota akan merasa puas, apabila mendapaat manfaat tertentu yang dapat memberikan kepuasan yang tidak didapatkan di tempat lain. Minat anggota dalam melakukan pembelian merupakan cermin dari keberhasilan koperasi dalam memerankan fungsinya, dan kepuasan anggota merupakan salah satu tujuan koperasi. Untuk mencapai tujuan tersebut unit toko koperasi harus selalu berusaha untuk memperbaiki pelayanan. Hal ini dilakukan agar kinerja kopegtel rajawali bisa sesuai dengan harapan anggota. Pelanggan memang harus dipuaskan, sebab kalau mereka tidak puas akan meninggalkan, sehingga berdampak pada penurunan penjualan dan pada gilirannya akan menurunkan pendapatan dan bahkan kerugian.

\section{B. Perumusan Masalah}


Berdasarkan latar belakang penelitian, maka permasalahan dapat diidentifikasikan sebagai berikut:

1. Bagaimana pelaksanaan dari pelayanan yang dilakukan oleh Kopegtel Rajawali ?

2. Bagaimana peran Kopegtel Rajawali dalam memberikan kepuasan kepada anggotanya ?

\section{Tujuan Penelitian}

Tujuan penelitian ini adalah untuk memberikan jawaban atas pertanyaan khusus di atas. Adapun tujuan penelitian adalah:

1. Untuk mengetahui bagaimana proses pelaksanaan pengadaan barang konsumsi yang dilakukan oleh unit toko Kopegtel Rajawali.

2. Untuk mengetahui bagaimana peran unit toko Kopegtel Rajawali dalam memuaskan anggotanya.

\section{TINJAUAN PUSTAKA}

\section{A. Pengertian Manajemen Pemasaran}

Menurut Kotler yang dimaksud dengan manajemen pemasaran adalah proses perencanaan dan pelaksanaan dari perwujudan, pemberian harga, promosi, dan distribusi dari barang-barang, jasa dan gagasan untuk menciptakan pertukaran dengan kelompok sasaran yang memenuhi tujuan pelanggan dan organisasi (Philip Kolter; 2000:9). Definisi lain yang senada dikemukakan oleh Kotler dan Gary Amstrong (1996:91) adalah analisis perencanaan, pelaksanaan dan mempertahankan pertukaran yang menguntungkan dengan pembelian sasaran dengan maksud untuk mencapai sasaran organisasi.

Pemasaran dan produksi merupakan fungsi pokok bagi perusahaan. Semua perusahaan berusaha memproduksi dan memasarkan produk atau jasa untuk memenuhi kebutuhan konsumen. Pada saat ini kegiatan pemasaran mempunya peranan yang sangat penting dalam dunia usaha. Kadang - kadang istilah pemasaran ini diartikan sama dengan beberapa istilah, seperti: penjualan, perdagangan dan distribusi. Pemasaran merupakan konsep yang menyeluruh, sedangkan istilah yang lain tersebut hanya merupakan satu bagian, satu kegiatan dalam sistem pemasaran secara keseluruhan, jadi pemasaran merupakan keseluruhan dari pengertian tentang penjualan, perdagangan dan distribusi (Swastha dan Sukotjo, 2010:178).

\section{B. Pasar dan Pemasaran}

Pasar didefinisikan sebagai orangorang yang mempunyai kebutuhan untuk dipuaskan, mempunyai uang untuk dibelanjakan dan kemauan untuk membelanjakan (Stanton, 1994:92). Dari definisi tersebut dapat disimpulkan bahwa tiga faktor yang melandasi istilah pasar tersebut yaitu, kebutuhan, daya beli mereka dan perilaku mereka.

Menurut Kotler (1997:12) yang dimaksud dengan pasar adalah "pasar terdiri dari semua pelanggan potensial yang memiliki kebutuhan atau keinginan tertentu yang sama, yang mungkin bersedia dan mampu melaksanakan pertukaran untuk memuaskan kebutuhan dan keinginan itu". Dari definisi tersebut bahwa ukuran pasar bergantung pada jumlah orang yang menunjukkan kebutuhan dan keinginan itu.

Pemasaran merupakan suatu proses sosial dan manajerial yang di dalamnya individu dan kelompok mendapatkan apa yang mereka butuhkan dan inginkan dengan menciptakan, menawarkan dan mempertukarkan produk yang bernilai dengan pihak lain.

Sedangkan pemasaran merupakan suatu proses sosial dan manajerial yang di dalamnya individu dan kelompok 
mendapatkan apa yang mereka butuhkan dan inginkan dengan menciptakan, menawarkan dan mempertukarkan produk yang bernilai dengan pihak lain. Definisi pemasaran ini bersandar pada konsep inti berikut kebutuhan (need), keinginan (want) dan permintaan (demand), produk (barang, jasa dan gagasan), nilai, biaya dan kepuasan pertukaran dan transaksi hubungan dan jaringan, pasar, serta pemasaran dan prospek.

Aktivitas pemasaran bermula dari pengamatan kebutuhan konsumen. Sebuah cara menganalisis kebutuhan mereka adalah dengan mencari tahu mengapa orang membeli barang atau jasa. Setiap barang dan jasa dijual untuk memenuhi kebutuhan orang per orang dan keluarga. Kebutuhan mereka amat bervariasi dari yang sederhana, seperti makan, minum, pakaian, tempat tinggal, transportasi, kerapihan, telekomunikasi, dan lain- lain termasuk hiburan (Ma'ruf, 2003:5).

Pasar merupakan orang - orang yang mempunyai keinginan untuk puas, uang untuk berbelanja dan kemauan untuk membelanjakan. Dari definisi tersebut dapat diketahui dalam pasar terdapat 3 unsur penting, yaitu, orang dengan segala keinginan, daya beli mereka dan kemauan untuk membelanjakan uangnya (Swastha dan Sukotjo, 2001:191).

Pemasaran berhubungan dengan mengidentifikasi dan memenuhi kebutuhan masyarakat. Salah satu dari definisi pemasaran terpendek adalah memenuhi kebutuhan secara menguntungkan (Kotler dan Keller, 1997:6). Pemasaran merupakan kegiatan memasarkan barang atau jasa umumnya kepada masyarakat dan khususnya kepada pembeli potensial (Ma'ruf, 2003:1).
Menurut Asosisasi pemasaran Amerika dalam Kotler dan Keller (1997:6), pemasaran merupakan satu fungsi organisasi dan seperangkat proses untuk menciptakan, mengomunikasikan dan menyerahkan nilai kepada pelanggan dan mengelola hubungan pelanggan dengan cara yang menguntungkan organisasi dan para pemilik sahamnya. Manajemen pemasaran merupakan seni dan ilmu memilih pasar sasaran dan mendapatkan, menjaga dan menumbuhkan pelanggan dengan menciptakan, menyerahkan dan mengkomunikasikan nilai pelanggan yang unggul (Kotler dan Keller, 1997:6). Manajemen pemasaran merupakanseni dan ilmu memilih pasar sasaran dan mendapatkan, menjaga, dan menumbuhkan pelanggan dengan menciptakan, menyerahkan dan mengkomunikasikan nilai pelanggan yang unggul (Kotler dan Keller, 2001:6).

\section{Pelayanan}

Pelayanan merupakan hal yang cukup penting dalam kegiatan unit usaha toko. Pelayanan dapat djadikan sebagai salah satu alat di dalam persaingan non harga dengan took lain. Guna meningkatkan partisipasi anggota dalam berbelanja di unit toko, upaya peningkatan pelayanan ini harus dikembangkan agar usaha koperasi dapat tetap berjalan dengan baik, seperti yang dikemukakan oleh Kotler bahwa jenis persaingan baru berlangsung bukannya antar produk yang baru diproduksi oleh perusahaan-perusahaan di pabrik, melainkan antar segala macam yang mereka tambahkan pada hasil pabrik tersebut.

Kualitas pelayanan adalah ukuran sejauh mana pelayanan yang diberikan dapat memenuhi harapan pelanggan (Assegaf, 2001:173). Kualitas pelayanan 
adalah tingkat keunggulan yang diharapkan dan pengendalian atas tingkat keunggulan tersebut untuk memenuhi keinginan pelanggan. Dengan kata lain ada "dua faktor utama yang mempengaruhi kualitas jasa, yaitu expected service dan perceived service atau kualitas jasa yang diharapkan dan kualitas jasa yang di terima atau dirasakan. Apabila jasa yang diterima atau dirasakan sesuai dengan yang diharapkan, maka kualitas jasa dipersepsikan baik dan memuaskan. Jika jasa yang diterima atau dirasakan melampauiharapan pelanggan, maka kualitas jasa dipersepsikan sebagai kualitas yang sangat ideal. Sebaliknya jika jasa yang diterima lebih rendah dari yang diharapkan maka kualitas jasa dipersepsikan sebagai kualitas yang buruk (Tjiptono, 2000:59).

Setiap pelanggan mempunyai harapan tersendiri disaat memutuskan untuk memilih tempat penyedia jasa yang dibutuhkan. Menurut Kotler dan Amstrong, (2001:140) harapan pelanggan dibentuk berdasarkan pengalaman konsumen berbelanjaan pada masa lampau, opini teman dan kerabat, serta informasi dan janji-janji perusahaan dan para pesaing.

Menurut Zeithalm, et al (2005:50) harapan pelanggan terhadap jasa ada dua tingkat, yaitu:

1. Pelayanan Diinginkan

Merupakan tingkat pelayanan yang diinginkan pelanggan yang terdiri dari campuran tantangan apa yang pelanggan yakini dan seharusnya diterima.

2. Pelayanan Yang Memadai

Merupakan tingkatan pelayanan yang paling rendahyang akan diterima pelanggan. Pelayanan memadai merupakan pelayanan yang diberikan perusahaan dan masih diharapkan untuk dapat memenuhi kebutuhan dasar konsumen.

\section{Fundamentalis Service}

Pada dasarnya pelayanan terhadap pelanggan atau anggota tergantung dari latar belakang karyawan tersebut, baik suku bangsa, pendidikan, pengalaman, budaya atau istiadat. Namun agar pelayanan menjadi berkualitas dan memiliki keseragaman setiap karyawan perlu dibekali dengan pengetahuan yang mendalam tentang dasar - dasar pelayanan. Menurut Kasmir. SE. MM (2000:18) yang harus dipahami dan dimengerti seorang custumer service, pramuniaga, public relation, kasir maupun satpam adalah:

1. Berpakaian dan berpenampilan rapih dan bersih,

2. Percaya diri, bersikap akrab dan murah senyum,

3. Menyapa dengan lembut dan berusaha menyebut nama jika sudah kenal.

4. tenang, sopan, hormat, serta tekun mendengarkan setiap pembicaraan.

5. berbicara dengan bahasa yang benar dan baik.

6. Bergairah melayani pelanggan dan menunjukan kemampuannya.

7. Jangan menyela atau memotong pembicaraan.

8. Mampu meyakinkan pelanggan serta memberikan kepuasan.

9. Jika tidak sanggup menangani masalah yang ada, mintalah bantuan.

10. Bila belum dapat melayani, beritahukan kapan akan dilayani.

\section{E. Lima Determinan Kualitas Pelayanan}

Menurut kolter yang dikutip oleh Alma (2000:231) mengungkapkan ada lima faktor dominan atau kualitas pelayanan yaitu: keandalan, yaitu kemampuan untuk memberikan pelayanan sesuai dengan yang dijanjikan 
terpercaya dan akurat, konsisten dan kesesuaian pelayanan (reabibility).

1. Daya tanggap, yaitu kemauan dari karyawan dan pengusaha untuk membantu pelanggan dan memberikan pelayanan dengan cepat serta mendengar dan mengatasi keluhan yang diajukan oleh konsumen atau anggota (responsiveness).

2. Kepastian, yaitu berupa kemampuam karyawan untuk menimbulkan keyakinan dan kepercayaan terhadap janji yang telah dikemukakan kepada konsumen misalkan pelayanan dengan sopan santun dan ramah tamah (assurance).

3. Empati, yaitu kesediaan karyawan dan pengusaha untuk lebih peduli memberikan perhatian secara pribadi kepada konsumen.

4. Tangibles/berwujud, yaitu berupa penampilan fisik, peralatan dan berbagai materi komunikasi, enterior tata ruang, tidak berwujud berupa pelayanan merupakan suatu kinerja penampilan, tidak berwujud cepat hilang, lebih dapat dirasakan dari pada dimiliki.

Menurut Panasuraman, Zeithaml dan Berry (1988) dalam Tjiptono dan Chandra (2004:133), terdapat lima dimensi utama yang disusun sesuai urutan tingkat kepentingan relatifnya, adapun dimensinya adalah sebagai berikut:

1. Reliabilitas (Reliability)

Berkaitan dengan kemampuan perusahaan untuk memberikan layanan yang akurat sejak pertama kali tanpa membuat kesalahan apapun dan menyampaikan jasanya dengan waktu yang disepakati, seperti menyediakan jasa sesuai yang dijanjikan, dapat diandalkan dalam menangani masalah jasa pelanggan, menyampaikan jasa secara benar, menyampaikan jasa sesuai dengan waktu yang dijanjikan, menyimpan catatan atau dokumen tanpa kesalahan.

2. Daya Tanggap (Responssiveness)

Berkenaan dengan kesediaan dan kemampuan para karyawan untuk membantu para pelanggan dan merespon permintaan mereka, serta menginformasikan kapan jasa akan diberikan kemudian memberikan jasa secara cepat.

3. Jaminan (Assurance)

Perilaku para karyawan mampu menumbuhkan kepercayaan oleh pelanggan terhadap perusahaan dan perusahaan bisa menciptakan rasa aman bagi perlangganya. Jaminan juga berarti bahwa para karyawan selalu bersikap sopan dan menguasai pengetahuan dan keterampilan yang dibutuhkan untuk menangani setiap pertanyaan atau masalah pelanggan.

4. Empati (Empathy)

Perusahaan memahami masalah para pelangganya dan bertindak demi kepentingan pelanggan, serta memberikan perhatian personal kepada para pelanggan, sungguh-sungguh mengutamakan kepentingan pelanggan dan memiliki jam operasi yang nyaman

5. Bukti Fisik (Tangibles)

Berkenaan dengan daya tarik fasilitas fisik, perlengkapan dan material yang digunakan perusahaan serta penampilan karyawan

\section{F. Pengertian Pelayanan Prima (Service Excellent)}

Atep adya barata (2004:27) berpendapat pelayanan prima adalah kepedulian kepada pelanggan dengan memberikan layanan terbaik untuk memfasilitasi kemudahan pemenuhan kebutuhan dan mewujudkan kepuasannya, agar mereka selalu loyal kepada organisasi atau perusahaan. 


\section{G. Prinsip - Prinsip Kualitas Pelayanan}

Untuk menciptakan suatu gaya manajemen dan lingkungan yang kondusif bagi perusahaan jasa untuk memperbaiki kualitas pelayanan. Maka perusahaan harus dapat memenuhi enam prinsip utama yang berlaku bagi perusahaan jasa. Keenam prinsip tersebut penyempurnaan kualitas secara berkesinambungan dengan didukung oleh karyawan dan pelanggan. Menurut Wolkins, 1993 dalam (Anwar, 2009:22) ada enam prinsip pokok, meliputi:

\section{Kepemimpinan}

Strategi kualitas perusahaan harus merupakan inisiatif dan komitmen dari manajemen puncak, manajemen puncak harus memimpin perusahaan untuk meningkatkan kinerja kualitas dan karyawan. Tanpa ada kepemimpinan dari manajemen puncak, maka usaha untuk meningkatkan kualitas hanya berdampak kecil terhadap perusahaan.

2. Pendidikan

Semua personel perusahaan puncak sampai perusahaan oprasional harus memperoleh pendidikan mengenai kualitas. Aspek-aspek yang perlu mendapatkan tekanan dalam pendidikan tersebut meliputi konsep kualitas sebagai strategi bisnis, alat dan teknik implementasi strategi kualitas dan peranan eksekutif dalam implementasi strategi kualitas.

3. Perencanaan

Proses perencanaan strategi harus mencakup dan tujuan yang dipergunakan dalam mengarahkan perusahaan untuk mencapai visinya.

4. Review

Proses review merupakan satusatunya alat yang paling penting dan ekfetif bagi manajemen untuk mengubah prilaku organisasi. Proses ini merupakan suatu mekanisme yang menjamin adanya perhatian yang konstan dan terus menerus untk mencapai kualitas.

5. Komunikasi

Implementasi strategi kualitas dalam organisasi di pengaruhi olaeh proses komunikasi dalam perusahaan. Komunikasi harus dilakukan dengan karyawan, pelanggan, pemegang saham perusahaan, pemerintah, masyarakat umum dan lain-lain.

6. Penghargaan dan Pengakuan

Penghargaan dan pengakuan merupakan aspek implementasi strategi dalam perusahaan. Setiap karyawan yang berprestasi baiknya perlu di beri penghargaan dan prestasinya tersebut perlu diakui. Dengan demikian dapat meningkatkan motivasi, moral dan karyawan merasa bangga dalam rasa kepemilikan setiap organisasi, sehingga dapat memberikan kontribusi besar bagi pelanggan yang dilayani.

\section{H. Pengertian Kepuasan}

Menurut Day yang dikutip oleh Fandy Tjiptono (2000:146) menyatakan kepuasan pelanggan adalah respon pelanggan terhadap evaluasi ketidaksesuaian yang dirasakan antara harapan sebelumnya dan kinerja actual produk yang dirasakannya serta pemakaiannya.

Kepuasan pelanggan didefinisikan sebagai evaluasi kesadaran dan kecintaan pelanggan terhadap barang atau jasa. Andreassen (1994) mengatakan bahwa citra adalah sebuah faktor yang penting yang saling berhubungan dengan kepuasan pelanggan dan loyalitas pelanggan (Ariprabowo, 2001:24).

Kepuasan pelanggan menjadi salah satu hasil penting dari semua aktivitas pemasaran, sebab puas tidaknya 
pelanggan akan berdampak pada keberhasilan perusahaan. Oleh karena itu perusahaan selalu berusaha untuk dapat memuaskan pelanggannya atas barang/jasa yang telah diproduksinya (Widyaswati, 2001:17).

Swan, et.al (1980) dalam Tjiptono (2004:349) kepuasan pelanggan / konsumen sebagai evaluasi secara sadar atau penilaian kognitif menyangkut apakah kinerja produk relatif bagus atau jelek atau apakah produk bersangkutan cocok atau tidak cocok dengan tujuan atau pemakaian.

Menurut Tse dan Wilton dalam Tjiptono (2004:169) "kepuasan pelanggan adalah respon pelanggan terhadap evaluasi persepsi atas perbedaan antara harapan awal sebelum pembelian (atau standar kinerja lainnya) dan kinerja aktual produk sebagaimana dipersepsikan setelah memakai atau mengkonsumsi produk bersangkutan". Menurut Fornell dalam Tjiptono (2004:169) "Kepuasan pelanggan merupakan evaluasi purna beli keseluruhan yang membandingkan persepsi terhadap kinerja produk dengan ekspektasi pra-pembelian".

I. Metode Untuk Mengukur Kepuasan Pelanggan

Menurrut Kolter (1994:148) terdapat metode untuk mengukur kepuasan dari pelanggan, yaitu:

a. Sistem Keluhan dan Saran

Setiap perusahaan yang berorientasi pada pelanggan perlu memberikan kesempatan yang seluas-luasnya bagi para pelanggannya untuk menyampaikan saran, pendapat keluhan mereka.

b. Survei Kepuasan Pelanggan
Umumnya banyak penelitian mengenai kepuasan pelanggan dilakukan dengan menggunakan metode survei, baik melaui pos, telepon, maupun wawancara.

\section{c. Ghost Shopping}

Metode ini dilaksanakan dengan cara mempekerjakan beberapa orang untuk berperan sebagai pelanggan/anggota potensial produk perusahaan dan pesaing.

d. Lost customer analysis

Dalam metode ini perusahaan berusaha menghubungi para pelanggannya yang telah berhenti atau telah beralih pemasok, yang diharapkan adalah diperolehnya informasi penyebab terjadinya hal tersebut.

Menurut Rangkuti (2001:24) pengukuran tersebut dapat dilakukan dengan cara berikut:

\section{Direct reported satisfaction}

Pengukuran dilakukan secara langsung melalui pertanyaan kepada pelanggan dengan ungkapan sangat tidak puas, kurang puas, cukup puas, dan sangat puas.

2. Derived dissatisfaction

Pertanyaan yang diajukan menyangkut dua hal utama, yakni mengenai seberapa besar harapan pelanggan terhadap atribut tertentu dan besarnya kinerja yang mereka rasakan.

3. Problem analysis

Pelanggan yang dijadikan responden diminta mengungkapkan dua hal pokok. Pertama, masalah yang mereka hadapi berkaitan dengan penawaran dari perusahaan. Kedua, saran-saran untuk melakukan perbaikan.

4. Importance performance analysis Dalam tehnik ini, responden diminta meranking elemen atau atribut penawaran berdasarkan derajat kepentingan setiap elemen dan seberapa baik kinerja perusahaan pada masing-masing elemen. 


\section{METODE PENELITIAN}

Lokasi dalam penelitian ini adalah KOPEGTEL RAJAWALI KADATEL JAKARTA SELATAH milik PT. Telkom wilayah Jakarta Selatan yang beralamat di Jalan Sisingamangaraja No. 4 Jakarta Selatan. Metode yang digunakan dalam penelitian ini adalah metode studi kasus yang merupakan salah satu penelitian deskriptif, dengan studi ini diharapkan dapat diungkap secara mendalam variabel-variabel yang menggambarkan tentang analisis pemenuhan kebutuhan anggota terhadap barang konsumsi.

Data yang digunakan adalah menggunakan data primer dan data skunder. Data primer yang berupa wawancara beberapa dan berupa penyebaran kuesioner sedangkan dari data sekunder berupa daftar nama anggota beserta identitasnya, jumlah penjualan barang konsumsi setiap tahunnya, laporan RAT untuk beberapa periode, klasifikasi barang konsumen, data tentang pelaksanaan pengadaan barang konsumsi oleh koperasi, buku kegiatan usaha dan data tentang keadaan umum objek penelitian.

Teknik pengumpulan data dengan menggunakan wawancara dan observasi. Sampel yang dijadikan objek penelitian sebanyak 100 orang anggota KOPEGTEL Rajawali.

Data dan informasi yang diperoleh dari lapangan dianalisis dengan berpedoman kepada kerangka landasan analisis pada pendekatan masalah, yaitu untuk mengetahui penyediaan barang konsumsi apa saja yang disediakan oleh KOPEGTEL Rajawali akan diuraikan secara deskriptif, untuk mengetahui sejauh mana peran unit usaha toko dapat memenuhi kebutuhan anggota terhadap barang konsumsi kesesuaian akan dianalisis dengan menggunakan skala likert.

\section{HASIL DAN PEMBAHASAN}

A. Gambaran Umum Kopegtel Rajawali

1. Sejarah Berdirinya KOPEGTEL Rajawali

Pada mulanya PT.TELKOM sudah memiliki koperasi namun kurang maju, kemudian atas keinginan karyawan dan manajemen berdirilah kopegtel rajawali, usaha yang berbadan hokum SK KANWIL DEPKOP No. 2768/BH/I tanggal 10 september 1991, dan SK MENKOP PPK RI No. 186/PAD/KWK/III/1998 tanggal 31 maret 1998, yang didirikan pada tanggal 2 mei 1991, yang anggotanya berdiri dari seluruh karyawan PT. TELKOM DATEL SELATAN yang ada, keberadaan koperasi ini tidak banyak memberikan manfaat bagi anggotanya. Hal ini disebabkan oleh ketidak mampuan pengurus dalam menyerap aspirasi anggota meskipun sudah banyak anggota yang memberikan kritik dan saran untuk kemajuan koperasi.

Kopegtel Rajawali yang semula usaha dalam bidang kebutuhan pokok serta simpan pinjam yang masih minim. Dengan fenomena tersebut di atas, perusahaan yang dapat mengeluarkan kebijaksanaan koperasi bisa dan mampu memberikan kontribusi pada proyek-proyek PT. TELKOM dan menjalin kerjasama dengan pihak-pihak ketiga. Perubahan sangat cepat dengan dihapuskannya PT. TELKOM sebagai perusahaan monopoli yaitu undang-undang No. 5 tahun 1999 berlaku mulai tanggal 5 Maret 1999 tentang larangan praktek monopoli dan persaingan usaha tidak sehat. Kesempatan ini tidak disiasiakan oleh manajemen dan Kopegtel 
berperan aktif untuk memberikan kontribusi kepada karyawan melalui pelayanan prima.

2. Visi, Misi dan Strategi Kopegtel Rajawali.

Visi : Menjadi Koperasi yang mandiri dan bernilai tinggi.

Misi : Menyediakan dan dapat memberikan layanan yang memuaskan bagi anggota, pelanggan dan masyarakat, melalui pengelolaan sumber daya secara optimal. Menerapkan pemasaran yang efektif dan efisien untuk memenuhi kebutuhan dan keinginan pelanggan/anggota. Menciptakan interpendensi mutualistik antara koperasi, mitra dan anggota. Mengembangkan usaha bisnis koperasi, untuk meningkatkan pelayanan dan kepuasan anggota serta kesejahteraan anggota.

Strategi : melakukan penetrasi pasar. Melakukan konsolidasi internal dan eksternal dalam bidang usah. Mengembangkan bidang usaha yang memberikan keuntungan tinggi dengan meminimize resiko kecil. Melakukan restrukturisasi usaha yang kurang menguntungkan.

3. Struktur Organisasi Dari Kopegtel Rajawali.

Organisasi merupakan suatu wadah yang di dalamnya terdapat dua orang atau lebih yang bekerja sama dalam mencapai tujuan bersama. Adapun struktur organisasi dari Kopegtel Rajawali adalah sebagai berikut:
Gambar. 1 Struktur Organisasi

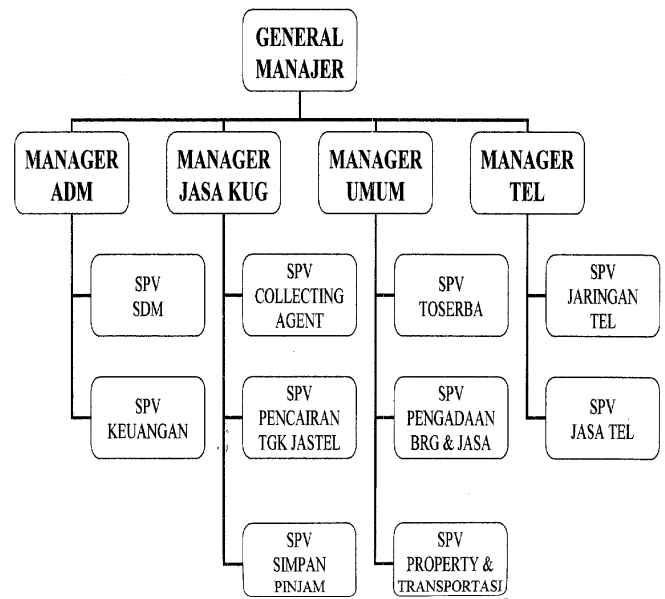

4. Hasil Analisa

1. Analisa Kepuasan Anggota Terhadap Pelayanan KOPEGTEL Rajawali

Berdasarkan hasil jawaban kuesioner yang dilihat dari faktorfaktor yang mempengaruhi kepuasan anggota/pelanggan adalah sebagai berikut:

a. Analisa Kehandalan, Kemampuan manajemen Kopegtel Rajawali yang tidak terbelit-belit sehingga tugas dan tanggung jawab dapat diselesaikan dengan cepat dan tepat serta semua pelayanan diarahkan untuk mendukung kualitas pelayanan yang berorientasi terhadap kepentingan pelanggan/anggota.

b. Analisa Ketanggapan, terdiri dari:

i. pelayanan di service point untuk menghindari antrian panjang, di dalam bagian ini dijelaskan mengenai tingkat kepentingan secara rinci agar tidak menimbulkan antrian yang panjang sehingga pelanggan/anggota tidak menunggu terlalu lama, akan 
tetapi pelayanan tetap dilakukan dengan cepat dan akurat

ii. kecepatan dalam memberikan informasi bila terjadi kerusakan teknis / computer off di dalam bagian ini Kopegtel wajib menyampaikan pemberitahuan kepada anggota dengan segera setelah diketahui bila pelayanan diserpo akan mengalami keterlambatan,.

iii. kesediaan pegawai menjawab pertanyaan bila terjadi keterlambatan pembayaran SHU, ketanggpan pegawai menjawab pertanyaan anggota akan mencerminkan suatu perhatian Kopegtel terhadap anggotanya.

c. Analisa Keunggulan,

i. help desk yang efektif dan selalu membantu dalam segala hal, di dalam bagian ini berarti pihak Kopegtel Rajawali menyediakan counter khusus dengan stafnya yang selalu siap sedia membantu dan memberikan informasi sesuai dengan keinginan anggota.

ii. kemudahan menghubungi dengan petugas, keberadaan petugas yang selalu ditempat dan bersedia menyelesaikan masalah dari keluhan anggota, akan dapat memberikan kesan yang baik kepada anggota dan mereka tidak akan terlalu kecewa.

iii. kesungguhan mendengarkan dan menyelesaikan masalah serta memahami keinginan anggota. Pengertian ini menurut kemampuan pihak perusahaan untuk dapat memenuhi keinginan dan kebutuhan anggotanya merupaka nilai tambah bagi perusahaan, di mana pihak perusahaan dapat mengerti dan menganalisis kebutuhan dan keinginan anggota.

d. Analisa Perhatian Khusus, Pegawai Kopegtel ikut merasakan apa yang dirasakan anggota. Ikut memperhatikan keluhan-keluhan anggota, dan melayani semua anggita tanpa memandang status sosial dan lain sebagainya

e. Analisa Fasilitas, Kopegtel Rajawali memiliki fasilitas dan sarana yang baik. Merupakan faktor- faktor yang dianggap saat berpengaruh pula terhadap kualitas, layanan, fisik atau layanan jasa yang diberikan kepada anggota oleh kopegtel rajawali yaitu fasilitas atau saran dan prasarana serta interior tata ruang yang disediakan.

\section{Pelaksanaan Pelayanan dan Kepentingan Anggota Kopegtel Rajawali}

Berdasarkan kebutuhan dan keinginan serta tingkat kepuasan yang berbeda-beda terhadap layanan maka kopegtel berusaha semaksimal mungkin untuk memenihi keinginan tersebut, sehingga peran kopegtel rajawali meningkat. Kopegtel rajawali menjual barang-barang kebutuhan pokok dengan cara tunai dan kredit, hal ini dilakukan agar anggota dapat merasakan manfaat yang lebih dari koperasi dalam memeberikan pelayanan kelitka melakukan pembayaran secara kredit. Dalam melaksanakan tugas oprasionalnya diunit-unit kopegtel rajawali memeberikan jaminan layanan yang menacu kepada dasar-dasar kualitas pelayanan agar anggota merasa terkesan dan puas. 
Berikut hasil jawaban responden mengenai pelaksanaan pelayanan dan kepentingan anggota Kopegtel Rajawali:

a. Ketepatan Waktu Pelayanan Berdasarkan penilaian di lapangan ketepatan waktu pelayanan yang dilaksanakan Kopegtel Rajawali menurut sebagian anggota dinilai baik, hal ini berdasarkan hasil jawaban kuesioer. Perbedaan pendapat yang kecil mengenai ketepatan waktu pelayanan yang dilakukan Kopegtel Rajawali disebabkan karena ada perbedaan kepentingan, adanya anggota yang acuh tak acuh terhadap keberadaan Kopegtel Rajawali. Selanjutnya dari hasil penelitian pada tingkat kepentingan terhadap ketepatan waktu dinilai sangat penting.

b. Prosedur Pelayanan Kopegtel Rajawali

Berdasarkan hasil penilaian di lapangan prosedur pelayanan KOPEGTEL Rajawali sangat baik dan tingkat kepentingan terhadap prosedur pelayanan sangat penting.

c. Ketepatan Jam Kerja / Jadwal Pelayanan

Jadwal pelayanan Kopegtel Rajawali baik dan tingkat kepentingan dinilai oleh anggota Kopegtel Rajawali sangat penting.

d. Kemudahan Mendapatkan

Pelayanan Kopegtel Rajawali

Kemudahan pelayanan yang diberikan Kopegtel Rajawali dinilai baik dan tingkat kepentingan dinilai sangat penting.

e. Keramahan Pegawai/Pengurus Kopegtel Rajawali

Keramahan pegawai dinilai sangat baik dan berdasarkan tingkat kepentingan dinilai sangat penting. f. Pengetahuan dan Kecakapan Pegawai

Pengetahuan dan kecakapan dinilai baik dan berdasarkan tingkat kepentingan dinilai sangat penting.

g. Tanggung Jawab Pegawai dan Pengurus KOPEGTEL Rajawali

Hasil penelitian menunjukkan bahwa tingkat tanggung jawab pegawai dinilai baik dan berdasarkan tingkat kepentingan dinilai sangat penting.

h. Pelayanan Yang Adil Oleh KOPEGTEL Rajawali

Hasil penelitian keadilan pelayanan dinilai baik dan berdasarkan kepentingan dinilai sangat penting.

i. Perhatian Khusus Pegawai Kopegtel Rajawali

Hasil penelitian menyatakan perhatian khusus pegawai dinilai kurang baik dan berdasarkan tingkat kepentingan dinilai penting.

j. Ketanggapan Pengurus/Pegawai Terhadap Masalah Yang Timbul

Berdasarkan penelitian dinilai ketanggapan pengurus/pegawai terhadap masalah yang timbul dinilai kurang baik sedangkan tingkat kepentingan anggota dinilai penting.

k. Ketanggapan Terhadap Keluhan Anggota KOPEGTEL Rajawali

Berdasarkan hasil penelitian dilapangan bahwa pelaksanaan menanggapi keluhan anggota adalah kurang baik sedangkan tingkat kepentingan anggota dinilai penting.

1. Kemampuan Pegawai/Pengurus Dalam Berkomunikasi

Berdasarkan hasil penelitian kemampuan pegawai dalam berkomunikasi dinilai kurang baik sedangkan tingkat kepentingan menilai sangat penting.

m. Kebersihan Kopegtel Rajawali 
Hasil penelitian menyatakan bahwa kebersihan dinilai baik sedangkan tingkat kepentingan adalah sangat penting.

n. Penampilan Pegawai/Pengurus Kopegtel Rajawali

Hasil penelitian menyatakan dinilai baik sedangkan tingkat kepentingan atau harapan anggota dinilai sangat penting.

o. Tata Ruang dan Enterior Kopegtel Rajawali

Berdasarkan hasil penelitian tata ruang dan enterior kopegtel rajawali dinilai kurang baik sedangkan tingkat kepentingan dinilai penting.

p. Kelengkapan Perlengkapan dan Peralatan Kopegtel Rajawali

Berdasarkan hasail penelitian anggota menilai baik sedangkan tingkat kepentingan dinilai penting.

\section{Penilaian Anggota Terhadap \\ Pelaksanaan, Kepentingan Atas Pelayanan KOPEGTEL Rajawali}

Pengukuran dari tingkat
pelaksanaan dan kepentingan,
pelayanan Kopegtel Rajawali dapat
dilihat dari indikator-indikator
pelayanan yang disajikan oleh
Kopegtel Rajawali yang bertujuan
memuaskan anggota. Jumlah skor
untuk tingkat pelaksanaan dan
kepentingan pelayanan yang telah
dilaksanakan oleh Kopegtel Rajawali.
Tingkat kepentingan anggota atas
pelayanan yang disajikan Kopegtel
Rajawali bahwa sebagian besar
anggota merasa sangat penting dan
hanya empat unsur pelayanan yang
dianggap penting adalah:
a. Kemampuan dalam menghadapi
masalah
b. Kerapihan petugas
c. Tata ruang dan enterior

d. Kelengkapan perlengkapan dan peralatan

Selanjutnya unsur pelayanan yang lainnya dianggap sangat penting, kemudian anggota cenderung menilai baik pelaksanaan pelayanan, namun belum maksimal. Untuk mengetahui lebih lanjut sejauh mana tingkat kesesuaian pelaksanaan dan tingkat kepentingan digunakan formulasi sebagai berikut:

$$
\begin{array}{|cc|}
\text { TK Kepuasan } & =\frac{\text { Tingkat Pelaksanaan }}{\text { Tingkat Kepentingan }} \text { X } 100 \\
\text { Setelah diketahui tingkat }
\end{array}
$$
kepuasan anggota atas pelaksanaan dari masing-masing unsur dari pelayanan, maka dapat diketahui pelaksanaan seluruh unsur pelayanan yang dapat diformulasikan sebagai berikut:

$$
\text { TK Kepuasan }=\frac{\text { Tingkat Pelayanan }}{\text { Tingkat Kepentingan }} \times 100
$$

Dengan asumsi TK Kepuasan $=\mathrm{TK}$ Kesesuaian.

$$
\text { Rumus Interval }=\frac{\text { Skor Kumulatif Tertinggi }- \text { Skor Kumulatif Terendah }}{\text { Kriterial Pilihan }}
$$

Selanjutnya untuk menentukan tingkat tinggi atau rendahnya nilai indikator, menggunakan rumus di atas. Didapat dari responden sebanyak 100 orang maka diperoleh hasil:

Skor K. Tertinggi : 100 X $5=500$

Skor K. Terendah : 100 X $1=100$

Sehingga interval yang didapat:

$$
\text { Rumus Interval }=\frac{500-100}{5}
$$

Maka kelas interval yang didapat adalah sebagai berikut

Tabel. 1 


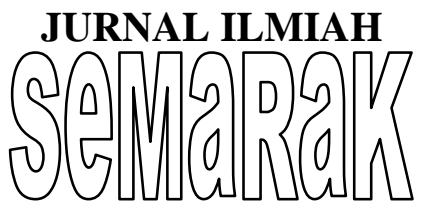

P-ISSN 2615-6849

Jurnal Semarak,Vol. 1,No.1,Februari 2018 , Hal (13-30)

@Prodi Manajemen Fakultas Ekonomi Universitas Pamulang

\section{Hasil Interval}

\begin{tabular}{|c|c|l|}
\hline No. & Kelas Interval & \multicolumn{1}{|c|}{ Keterangan } \\
\hline 1. & $100-179$ & Sangat tidakbaik/ sangat tidakpenting \\
2. & $180-259$ & Kurang Baik/Kurang Penting \\
3. & $260-339$ & Tidak Baik/ Tidak Penting \\
4. & $340-419$ & Baik/ Penting \\
5. & $420-499$ & Sangat Baik/ Sangat Penting \\
\hline
\end{tabular}

Pelaksanaan Kepentingan Pelayanan

\begin{tabular}{|c|c|c|c|c|c|}
\hline & \multirow{2}{*}{ lous Ptayuatal } & \multicolumn{2}{|c|}{ Pelakouate } & \multicolumn{2}{|c|}{ Keppotilinat } \\
\hline & & sklor & Interprital & stor & lateprotats \\
\hline & Kettpotan Wijta & 345 & Baile & 493 & Sglpenting \\
\hline & Postdur Playman & 34 & Bailik & 486 & Sylentiong \\
\hline t. & Jadwal Pdyynan & 421 & Bails & 498 & Stplenting \\
\hline & Kemudahan Pdayawan & 409 & Bail, & 495 & Snlention \\
\hline$t$ & 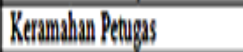 & 400 & Buil. & 494 & Smenting \\
\hline 1 & 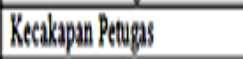 & 372 & Bith & 39 & finting \\
\hline & 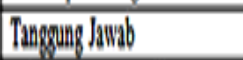 & 969 & Bialk & $\$ 00$ & Smenting \\
\hline $\int$ & Pdywand Ying AdI & 139 & Bitik & 49 & splenting \\
\hline 9 & Pertibinin Whisus & 32 & Bitilk & 49 & Stpenting \\
\hline$\prod_{1}$ & 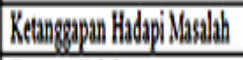 & 906 & BifBill & 36 & Pening \\
\hline$I_{1}$ & 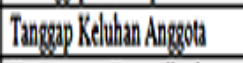 & 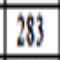 & Bifibilk & 486 & Syitioning \\
\hline 2. & Kmampuan Komunilkas' & 99 & MugBalik & 484 & Sytpenting \\
\hline 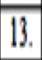 & Kebershus & 34 & Krg Bilk & 498 & Sglenting \\
\hline 4. & Penampilan Ptups & 346 & Bailk & 493 & Sytpenting \\
\hline 2 & Kenpilua Ptuges & 300 & KrgBaik & 360 & Pentang \\
\hline 16. & Enteno Tat Ruan & 32 & KupBik & 36 & Pening \\
\hline$T_{1}$ & 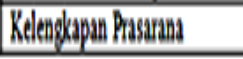 & 360 & Bitik & 386 & Pening \\
\hline
\end{tabular}

Berdasarkan hasil penelitian terlihat bahwa tingkat pelaksanaan pelayanan KOPEGTEL Rajawali yang berorientasi pada kepuasan pelanggan dilaksanakan dengan baik namun belum maksimal kenyataannya masih banyak anggota yang menilai kurang baik dan anggota sebagian besar menilai bahwa unsur - unsur pelayanan adalah sangat penting.

\section{Tingkat kepuasan anggota tehadap pelayanan kopegtel rajawali}

Sesuai penelitian tabel dibahwa ini telah diketahui ternyata pihak
KOPEGTEL Rajawali belum bisa sempurna $100 \%$ melaksanakan apa yang diinginkan oleh anggota seluruhnya kopegtel rajawali mampu merealisasikan sebesar 75,31\%.

Tabel. 3

\section{Hasil Penelitian Kepuasan Anggota} Terhadap

Pelaksanaan Unsur-Unsur Pelayanan

\begin{tabular}{|c|c|c|c|}
\hline Unsur Pelayanan & $(\Delta)$ & \begin{tabular}{|l|l|l|}
1 & 1 \\
\end{tabular} & $(\%)$ \\
\hline 1. Ketepatan Waktu & 345 & 49369 & 69,98 \\
\hline 2. Prosedur Pelayanan & 348 & 48671 & 71,60 \\
\hline 3. Jadual Pelayzanan & 421 & 49884 & 84,54 \\
\hline 4. Kemudahan Pelayanan & 409 & 49582 & 82,63 \\
\hline 5. Keramalinan Petuyas & 420 & $\begin{array}{lll}494 & 85 \\
\end{array}$ & 85,02 \\
\hline 6. Reachapan Petugas & 372 & 3997 & 74,55 \\
\hline 7. Tangongogrovarab & 364 & 50074 & 74,55 \\
\hline 8. Pelayanan Yang Adill & 357 & $\begin{array}{lll}49172 \\
\end{array}$ & 72,80 \\
\hline 9. Perhadian Khusus & 352 & 49271 & 71,54 \\
\hline 10. Ketangrgapan Hadapi Masalah & 305 & 3837 & 79,63 \\
\hline 11. Tangegap Keluhan Angogota & 283 & 4865 & 58,23 \\
\hline 12. Kemamplan Komulakgi & 295 & 4846 & 60,95 \\
\hline 13. Kebershlan & 341 & 4988 & 86,77 \\
\hline 14. Penampilan Petugas & 346 & 4937 & 70,18 \\
\hline 15.) Reraphan Petugas & 308 & 3508 & 88,00 \\
\hline 16. Enterior Yath Ruang & 322 & 3698 & 87,26 \\
\hline 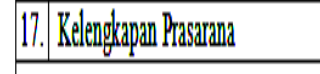 & 360 & 3869 & 93,26 \\
\hline Jumah & 5948 & 18897? & 15,3] \\
\hline
\end{tabular}

\section{Keterangan:}

$\mathrm{X}=$ Tingkat Pelaksanaan $\mathrm{Y}=$ Tingkat Kepentingan $\%=$ Tingkat Kepuasan

\section{Prioritas Peningkatan Layanan} Berdasarkan Diagram Kartesius

Skor tingkat pelaksanaan dan skor tingkat kepentingan atas semua unsur pelayanandigambarkan dalam diagram 


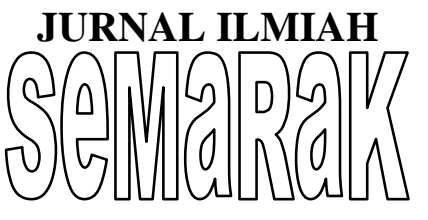

P-ISSN 2615-6849

Jurnal Semarak,Vol. 1,No.1,Februari 2018 , Hal (13-30)

@ Prodi Manajemen Fakultas Ekonomi Universitas Pamulang

kartesius. Berikut adalah gambar dari diagram kartesius:

Grafik 1

Diagram Cartesius

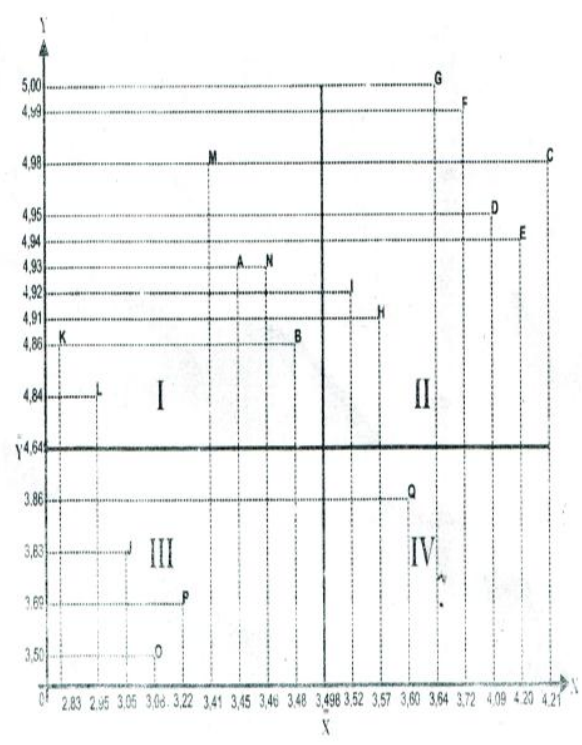

Keterangan:

$$
(\mathrm{X}, \mathrm{Y}) \quad=(3,498: 4,645)
$$

$$
\begin{array}{lll}
\mathrm{A} & =(3,45: 4,93) & \text { Ketepatan Waktu } \\
\mathrm{B} & =(3,48: 4,86) & \text { Prosedur Pelayanan } \\
\mathrm{C} & =(4,21: 4,98) & \text { Jadwal Pelayanan } \\
\mathrm{D} & =(4,09: 4,95) & \text { Kemudahan } \\
\text { Pelayanan } & \\
\mathrm{E} & =(4,20: 4,94) & \text { Keramahan Petugas } \\
\mathrm{F} & =(3,72: 4,99) & \text { Pengetahuan dan } \\
& & \text { Kecakapan } \\
\mathrm{G} & =(3,64: 5,00) & \text { Tanggung Jawab } \\
\mathrm{H} & =(3,57: 4,91) & \text { Pelayan Yang } \\
& & \text { Adil } \\
\mathrm{I} & =(3,52: 4,92) & \text { Perhatian Khusus } \\
\mathrm{J} & =(3,05: 3,83) & \text { Ketanggapan Atas } \\
& & \text { Masalah } \\
\mathrm{K} & =(2.83: 4,86) & \text { Tanggap Atas } \\
& & \text { Keluhan Pelanggan } \\
\mathrm{L} & =(2,95: 4,84) & \text { Kemampuan } \\
& & \text { Berkomunikasi } \\
\mathrm{M} & =(3,41: 4,98) & \text { Kebersihan } \\
\mathrm{N} & =(3,46: 4,93) & \text { KOPEGTEL } \\
\mathrm{O} & =(3,08: 3,50) & \text { Kenampilan Petugas } \\
\mathrm{P} & =(3,22: 3,69) & \text { Tata Ruang Petugas }
\end{array}
$$

$\mathrm{Q} \quad=(3,60: 3,86) \quad \begin{aligned} & \text { Enterior } \\ & \text { Kelengkapan Sarana }\end{aligned}$ Dengan melihat diagram tersebut, maka dapat diperoleh gambaran kedudukan dan masingmasing unsur pelayanan yang uraiannya sebagai berikut:

Kuadran 1 :

Menunjukan bahwa unsur-unsur pelayanan yang berada pada kuadran ini penanganannya perlu untuk diprioritaskan karena unsur pelayanan ini dipandang sangat penting dan diharapkan oleh anggota, sedangkan pihak KOPEGTEL pelaksanaannya kurang baik. Adapun unsur pelayanan tersebut: ketepatan waktu, prosedur pelayanan, ketanggapan keluhan anggota, kemampuan dalam berkomunikasi, kebersihan, penampilan.

Kuandra 2:

Menunjukan bahwa unsur-unsur pelayanan yang berada pada kuadran ini pelaksanaannya perlu dipertahankan, karena apa yang dilakukan kopegtel rajawali sudah dapat dikatakan sesuai denhan kepentingan atau harapan anggota. Unsur-unsur tersebut adalah : jadwal pelayanan, kemudahan pelayanan, keramahan dari petugas/pengurus, pengetahuan/kecakapan, tanggung jawab, perhatian khusus, pelayanan yang adil.

Kuandra 3:

Menunjukan bahwa unsur-unsur ini dipandang penting oleh angota dibanding dengan unsur lainnya, dan pihak kopegtel telah melaksanakan dengan biasa-biasa saja. Adapun unsur-unsur tersebut : ketanggpan terhadap masalah, tata ruang/interior, kerapihan. 
Kuandra 4:

Menunjukan bahwa unsur-unsur pelayanan ini, dinilai anggotanya bisa berlebihan melaksanakannya, bila dibandingkan dengan kepentingan anggota atas unsur tersebut adalah: kelengkapan prasarana.

\section{Upaya Yang Harus Dilakukan Oleh Kopegtel Rajawali Untuk Meningkatkan Kepuasan Anggota.}

Untuk meningkatkan peran Kopegtel Rajawali dalam rangka memberikan kepuasan dalam pelayanan dengan cara:

1. Memperbaiki kinerja / layanan kopegtel rajawali:

a. Penanganan pelayanan dari anggota

Perlu diketahui bahwa kopegtel merencanakan pelayanan dengan melakukan sebagai berikut :

a) merekrut pegawai

b) menempati pegawai sesuai dengan keahlian.

c) memberikan pembekalan dasar - dasar pelayanan yang mendalam.

d) mengikutkan pegawai untuk seminar atau pelatih.

e) memberikan standar tertentu untuk layanan

Upaya lain yang harus dilakukan oleh Kopegtel Rajawali untuk meningkatkan kepuasan anggota jangan hanya teoritis / prosedural berorientasi pada kekuasaan pelanggan eksternal, namun pegawai juga harus diperhatiakan, praktek di lapangan diawasi, karena pegawai sekaligus sebagai pelanggan internal yang tidak kalah penting untuk diberikan perhatian yang layak kriteria lain yang diinginkan anggota / pelanggan yang di anggap sangat penting, misalnya perhatian yang khusus, tanggung jawab ini harus mendapat skala prioritas untuk dipenuhi. Selanjutnya kritik, saran dan keluhan anggota dijadikan acuan untuk proaktif dan inisiatif dalam rangka mengambil keputusan yang bertujuan untuk memberikan kepuasan anggota.

b. Unsur - unsur dari pelayanan Kopegtel Rajawali

Dasar - dasar pelayanan yang disajikan kopegtel rajawali ada lima faktor utama, yang dalam operasaional dijabarkan menjadi 17 unsu-unsur layanan, sesuai dengan jumlah kosioner yang dibagikan pada responden. Yang menghasilkan penelitian sebagai berikut:

a) 11 (sebelas) unsur layanan yang nilai baik yaitu: 1) ketepatan waktu pelayanan dengan total skor 3452 ) prosedur layanan dengan total skor 348. 30 jadwal layanan dengan total skor 421. \$)kkemudahan ;ayanan dengan total skor 409 5) keramahan petugas dengan total skor 420. 6) pengetahuan dan kecakapan dengan total skor 372. 7) tabnggung jawab +deng-an total skor -364. -*8) pelayanan yang adil dengan total skor 357. 9) perhatian khusus dengan total skor 352, 10) penampilan petugas dengan total skor 346, 11) kelengkapan saran dengan total skor 360. 
b) Perbedaan dari pendapat penilaian unsur-unsur layanan yang baik dan yang tidak baik sangat tajam, artinya pelayanan kopegtel ini belum maksimal yaitu ada 6 unsurunsur layanan yang dinilai kurang baik yaitu 1) kemampuan menghadapi masalah dengan total nilai skor 305, 2) tsnggsp keluahan anggota dengan total skor 283. 3) kemampuan berkomunikasi dengan total skor 295 4) kebersihan kopegtel dengan total skor 341 5) kerapihan petugas dengan total skor 308 6) tata ruang dan enterior dengan totat skor 322

Upaya meningkatkan pelayanan anggota Kopegtel Rajawali dalam memberikan pelayabnan yang bdrorientasi pasda kepuasan anggota kendali dipegang oleh manajer pelayanan PT. telkom.

2. Melihat kinerja yang telah dilakukan Kopegtel Rajawali sebagai koperasi yang bergerak dalam bidang pelayanan barang dan jasa teori dan pengertian servis adalah sebagai berikut:

1) Selfesteem

2) Memberi nilai pada diri sendiri

3) Exeed expectation: melampaui yang diharapkan anggota

4) Recover merebut kembali

5) Vision visi, tujuan jangka panjang

6) Improve untuk melakukan peningkatan

\section{KESIMPULAN DAN SARAN}

\section{A. Kesimpulan}

Dari hasil pembahasan-pembahasan yang telah penulis kemukakan dalam bab-bab sebelumnya serta ditunjang dengan penelitian yang dilakukan pada KOPEGTEL wilayah pusat, maka penulis menarik beberapa kesimpulan dan saransaran yang diharapkan dapat berguna bagi KOPEGTEL Rajawali adalah:

a. Unsur-unsur pelayanan yang dinilai anggota baik adalah a) ketepatan waktu pelayanan yang dilaksanakan oleh KOPEGTEL Rajawali, menurut sebagian kecil anggota menilai sangat baik yaitu 9 orang dengan skor 45 , selanjutnya 47 orang menilai baik dengan skor 188 dan 24 anggota menilai kurang baik dengan skor 72 , serta 20 anggota menilai tidak baik dengan skor 40, maka dapat disimpulkan ketepatan waktu pelayanan dengan total skor 345 adalah baik. b) prosedur pelayanan dinilai anggota yang menyatakan sangat baik 18 orang dan 42 orang menilai baik dengan total skor seluruhnya 348, yang dapat disimpulkan baik, c) jadwal pelayanan 421 yang kesimpulannya adalah baik dan 10 orang menilai kurang baik 4 orang menilai tidak baik. d) kemudahan pelayanan dengan total skor 409 yaitu 37 orang menilai sangat baik dan 39 orang menilai baik, serta 20 orang menilai kurang baik, kemudian 4 orang menilai tidak baik, sehingga dapat disimpulkan kemudahan pelayanan adalah baik. e) keramahan pegawai dinilai anggota dengan total skor 420 dengan keterangan 45 menilai sangat baik, 40 menilai baik dan 10 orang menilai kurang baik, sehingga dapat disimpulkan baik keramahannya. f) pengetahuan dan kecakapan dengan total skor 372 ini adalah baik kesimpulannya. $\mathrm{h}$ ) pelayanan yang adil dengan total skor 357 ini 
kesimpulannya baik pelayannya. i) perhatian khusus dengan total skor 352 ini juga dapat disimpulkan baik. j) penampilan tugas dengan total skor 346 dapat penulis simpulkan baik. k) kelengkapan sarana dan prasarana dengan total skor 360 dapat disimpulkan baik.

b. Perbedaan yang sangat berarti antara penilaian unsur-unsur pelayanan yang baik dan yang tidak baik ini menggambarkan kinerja KOPEGTEL yang berusaha mempertahankan pelanggan/anggota yang ada.

c. Tingkat kepuasan anggota dapat dilihat pada tabel 4.20, yaitu jumlah total skor tingkat pelaksanaan dibagi total skor tingkat kepentingan anggota lalu dikalikan $100 \%$, yaitu: $\underline{5948} \times 100 \%=75,31 \%$ 7897

Sehingga penulis dapat menarik kesimpulan, KOPEGTEL Rajawali mampu merealisasikan kepuasan anggota sebesat $75,31 \%$.

\section{B. Saran}

1. Sebaiknya KOPEGTEL Rajawali menjadikan teori Koperasi sebagai acuan dalam melaksanakan operasionalnya.

2. KOPEGTEL Rajawali dalam menentukan pemasok/rekanan harus selektif, agar barang-barang yang dijual KOPEGTEL berkualitas

3. Khusus Flexi kami usulkan mencari pemasok yang mau memberikan service yang cepat

4. KOPEGTEL Rajawali harus lebih sensitive lagi terhadap keluhan anggota/pelanggan

5. Pembagian SHU disesuaikan kontribusi anggota

6. Pertahankan unsur pelayanan yang dinilai kurang baik

7. Khusus Flexi dan spedy lakukan pemasaran secara langsung pada tempat-tempat yang strategis dan masuk pada kerumunan orang banyak.

\section{DAFTAR PUSTAKA}

Ated, Adya Baratha. 2004, Dasar-Dasar Pelayanan Prima, Penerbit Media Kompotindo.

Basu Swastha. 1996, Azas-Azas Marketing, Liberty Yogyakarta.

Bilson Simamora. 2001, Memenangkan Pasar Dengan Efektif, Penerbit Gramedia.

Bukhari Alma, Dr. 2000, Pemasaran Jasa, Penerbit Alpha Beta.

Cecep Hidayat. 1998, Manajemen Pemasaran, Badan Penerbit IPWI, Jakarta.

Fandy, Tjiptono. 2000, Manajemen Jasa, Penerbit Andi, Yogyakarta.

Gorys Keraf. 1989, Komposisi Kemahiran Berbahasa, Penerbit Nusa Indah, Flores Nusa Tenggara Timur.

H.R.M, Ramudi Ariffin, Ms. 1997, Ekonomi Koperasi, UPT IKOPIN.

Ign. Sukamdiyo. 1992, Manajemen Koperasi, Universitas Diponegoro, Semarang.

Jochen Ropke, Prof, Dr. 2000, Ekonomi Koperasi, Teori Dan Manajemen, Penerbit Salemba Empat, Bandung.

J. Supranto, Prof. 2001, Pengukuran Tingkat Kepuasan Pelanggan, Penerbit Rineka Cipta, Jakarta.

Kamsir, SE, MM. 2005, Etika Customer Service, Penerbit Rajawali Press.

Kolter, Philip. 1997, Manajemen Pemasaran. Analisys, Panning, Implementation And Control, Prenhalindo Indonesia, Jakarta.

Kolter, Philip. 1990, Marketing Of Principal, Prenhalindo Indonesia, Jakarta 